Received $\quad 15.12 .2017$

Reviewed 23.02.2018

Accepted 28.03.2018

A - study design

B - data collection

C - statistical analysis

D - data interpretation

$\mathbf{E}$ - manuscript preparation

F - literature search

\section{Estimating the runoff coefficient using the analytic hierarchy process}

\author{
Faiza LALLAM ${ }^{\text {ABDEF } ه}$, Abdesselam MEGNOUNIF ${ }^{\text {AEF }}$, \\ Abderrahman Nekkache GHENIM ${ }^{\text {AE }}$
}

University abou Bakr BelKaid, Faculty of Technology, Tlemcen BP 230, 13000 Chetouane Tlemcen, Algeria; e-mail: faizalallam@yahoo.fr; megnounif_aslam@yahoo.fr; megnounif_aslam@yahoo.fr

For citation: $\quad$ Lallam F., Megnounif A., Ghenim A.N. 2018. Estimating the runoff coefficient using the analytic hierarchy process. Journal of Water and Land Development. No. 38 p. 67-74. DOI: 10.2478/jwld-2018-0043.

\begin{abstract}
The runoff coefficient $(R C)$ is a parameter that is very often used in surface hydrology in order to characterize the drainage capacity of a watershed. The traditional estimate of this coefficient is often made from abacuses based on 2 or 3 parameters to the maximum. In this work, three numerical models are presented. Two models are based on experimental work. The first one is based on three criteria, namely the vegetation cover, the type of soil, and the slope. The second one considers the size of the watershed, the maximum daily rainfall and the type of soil. In practice, it is not easy to estimate the coefficient of runoff by simultaneously considering the influence of several criteria. In order to overcome this problem, a third model is developed and presented; it allows capitalizing the information from the first two models mentioned above. The objective of the present work is to be able to verify the comparability of these criteria and to assess the relative importance of each of them.
\end{abstract}

Key words: analytic hierarchy process (AHP), maximum daily rainfall, runoff coefficient, slope, soil type, vegetation cover, watershed surface

\section{INTRODUCTION}

The hydrological response of a watershed depend on physical environment and climate, on the one hand, and on its physical environment, on the other [GRZYWNA 2017]. Numerous parameters shape the appearance and evolution of a flood; the most important factors are, among others: topography, land use, soil type, human action, and others. The physical environment is therefore responsible for the conduct of these rains. Thus, for the same amount of rain a flood may or may not appear [BALADÈS et al. 2004]. It is clear that the best way to reduce the risk of flooding is to identify all the parameters related to this phenomenon and to estimate their impacts on runoff in order to be able to act and take the appropriate decisions to deal with this danger. One of the most important parameters in the flood study is the runoff coefficient $(R C)$. This coefficient is the ratio of the quantity of runoff water to the quantity of precipitated water. It is may be estimated using abacuses which are established on the basis of a large number of experiments carried out in watersheds or experimental plots of land with different morphometric characteristics and under different climatic conditions. The effective study of the $R C$ is a very complex operation because of the high number of criteria that affect this coefficient. Thus, determining the individual impact of each of the criteria seems to be a very difficult task to overcome and to deal with.

A new approach to environmental management must be developed, while taking into account the close functional relations between the different disciplines of influence, such as topography, hydrology, geotechnical, rural engineering, river hydraulics, etc. Considering the specificity of the problems related to 
surface runoff and the complexity of this phenomenon, it was considered appropriate to use the analytic hierarchy process (AHP) [SAATY 1990], which is a multiple criterion evaluation methodology, to take into account the different parameters and factors that manage the coefficient of runoff. This process (AHP) is a multi-criteria decision method which was developed by Thomas L. Saaty in the 1980s. This method allowed for the emergence of a very large number of applications, spread over a wide range of fields. For example, mention may be made of:

- applying the analytic hierarchy process (AHP) into the effects assessment of river training works [HACHOŁ et al. 2017];

- using the analytic hierarchy process in water resources planning: selection of flood control projects [WILLETT, SHARDA 1991];

- modelling of hydraulic and structural degradation of sewer and storm water pipelines [ENNAOURI, FUAMBA 2010]; a model is thus proposed for evaluating the overall condition of sewer pipes, while considering several degradation factors related to the functioning of the network and to the pipe itself, or to the surrounding of the network;

- an analytic network process approach for siting a municipal solid waste plant in the Metropolitan Area of Valencia (Spain) [ARAGONES et al. 2010];

- a localized disaster-resilience index to assess coastal communities based on an analytic hierarchy process (AHP) [ORENCIO, FUJI 2013];

- assessing factors affecting flood-induced public health risks in Kassala State of Sudan [ABBAS, ROUTRAY 2014];

- development of the integrated fuzzy analytical hierarchy process with multidimensional scaling in selection of natural wastewater treatment alternatives [OUYANG et al. 2015].

Our work focuses on the development of a numerical model that allows estimating the runoff coefficient $(R C)$ by integrating the impact of five criteria, namely vegetation cover, soil type, slope, maximum daily rainfall and surface area of the watershed. The first step consists of adapting the analytic hierarchy process (AHP) in order to determine a theoretical value of the runoff coefficient; two models are thus proposed. The first one takes into account three criteria, i.e. the vegetation cover, type of soil and slope; the second one considers other criteria, such as the maximum daily rainfall, the area of the watershed and the type of soil. The study is then validated using experimental abacuses. Then, a third model is proposed; it makes it possible to evaluate the runoff coefficient by combining all the criteria considered in the first two models. The present study aims to estimate the relative importance of each of these five criteria and to explain the impact of their variations on the value of the runoff coefficient.

\section{METHODS}

The analytic hierarchy process (AHP) is used to estimate the value of the runoff coefficient. This process is a multi-criteria decision-making method that can be applied in the quantification of qualitative characteristics, by means of its weighting. This method uses hierarchical structures to represent a problem and then to establish weights for each parameter. These weights are based on the opinions of expert groups [SAATY 1990]. The models proposed in this work are developed in two steps and represented by the blocks A and B (Fig. 1).

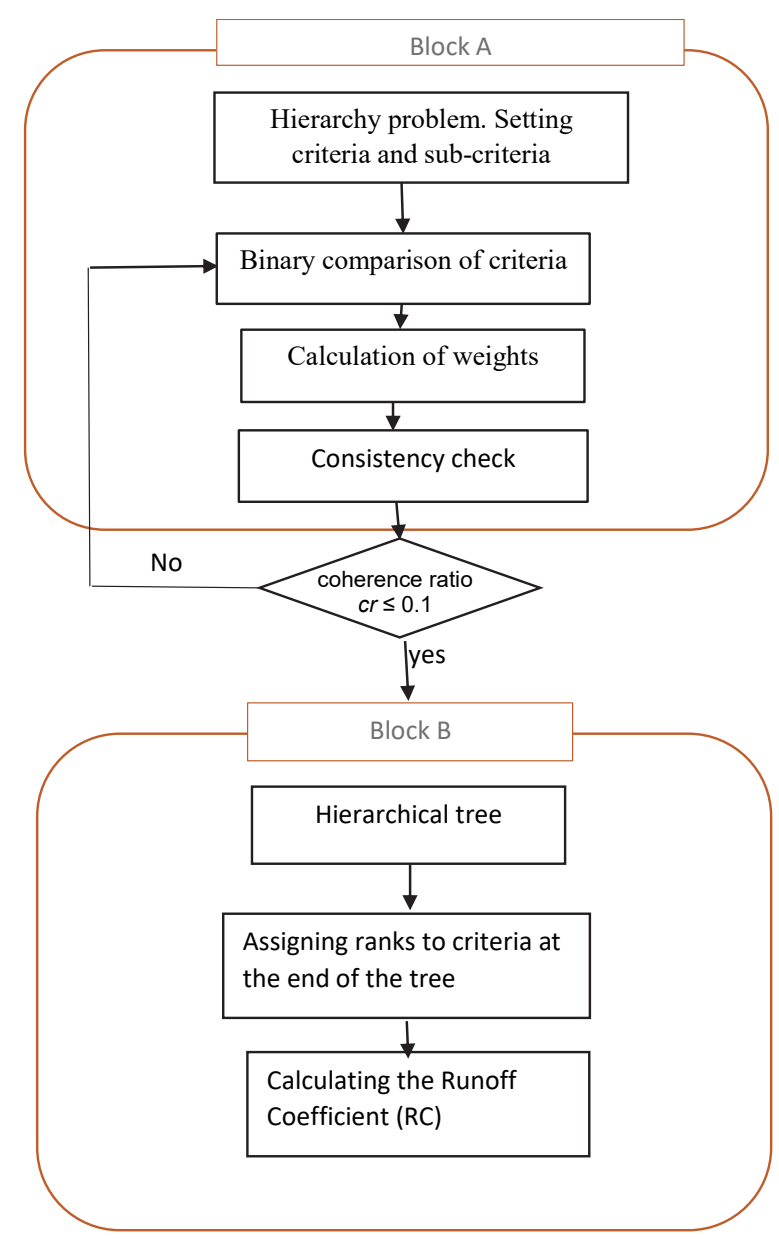

Fig. 1. Runoff coefficient $(R C)$ calculation procedure; source: ENNAOURI, FUAMBA [2010], modified

The coherence ratio $(c r)$ is used to check the consistency of the judgments defined in step 2 . If the value of the $\mathrm{cr}$ is less than $10 \%$, the weights obtained are preserved, if not the binary comparisons are modified until a satisfactory $c r$ value is reached.

In block $\mathrm{A}$, the complex problem is split up into a hierarchical structure by defining the target objective in level 0 , the criteria in level 1 , and the characteristics of these criteria in level 2 as shown in Figure 2. 


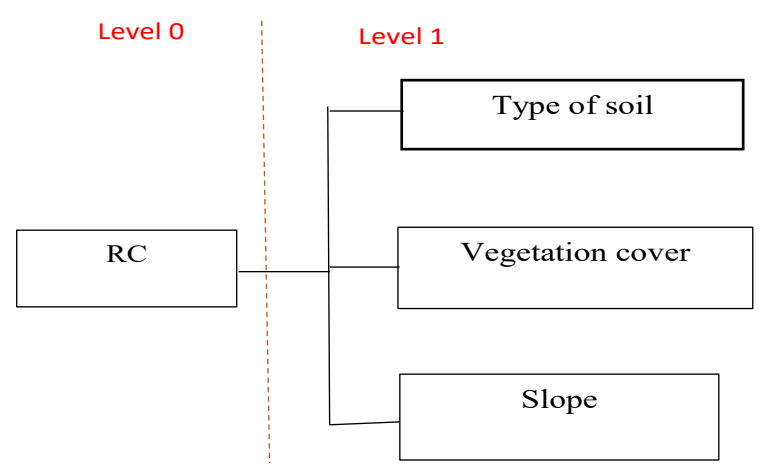

Fig. 2. The hierarchical structure of the runoff coefficient $(R C)$, model 1, source: own elaboration

For each level, from the top to the bottom of the hierarchy, the criteria are compared in a binary way, two by two, with respect to the upper criterion. From the construction of a square matrix (Tab. 1), the relative importance of one criterion is assessed with re- spect to another, using an appropriate scale. SAATY [1990] proposes using the scale illustrated in Table 2. Once the comparison matrix is filled, the eigenvalue as well as the corresponding eigenvector are calculated for each factor in the following manner.

Calculation of the sum of each column of the pairwise comparison matrix (Tab. 1); $B_{j}=\sum_{i} W_{i j}$, where $j$ is the suffix of the column, from 1 to $n$ and where $n$ is the number of elements to compare.

Table 1. Matrix of comparison

\begin{tabular}{|c|c|c|c|c|c|}
\hline Parameter & $C_{1}$ & $C_{2}$ & $C_{3}$ & $\ldots$ & $C_{n}$ \\
\hline$C_{1}$ & $W_{11}$ & $W_{12}$ & $W_{13}$ & $\ldots$ & $W_{1 n}$ \\
\hline$C_{2}$ & $W_{21}$ & $W_{22}$ & $W_{23}$ & $\ldots$ & $W_{2 n}$ \\
\hline$C_{3}$ & $W_{31}$ & $W_{32}$ & $W_{33}$ & $\ldots$ & $W_{3 n}$ \\
\hline$\ldots$ & $\ldots$ & $\ldots$ & $\ldots$ & $\ldots$ & $\ldots$ \\
\hline$C_{n}$ & $W_{n 1}$ & $W_{n 2}$ & $W_{n 3}$ & $\ldots$ & $W_{n \mathrm{n}}$ \\
\hline
\end{tabular}

Such as: $W_{i i}=1$ and $W_{i j}=1 / W_{i i}$.

Source: own elaboration.

Table 2. Numerical scale of analytic hierarchy process (AHP)

\begin{tabular}{|c|l|l|}
\hline $\begin{array}{c}\text { Degree of } \\
\text { importance }\end{array}$ & \multicolumn{1}{|c|}{ Definition } & Explanation \\
\hline 1 & the two criteria are equally important & two criteria contribute to one objective in the same way \\
\hline 3 & $\begin{array}{l}\text { one criterion is less important relative to } \\
\text { another }\end{array}$ & experience and personal appreciation slightly favor one criterion over another \\
\hline 5 & high or significant importance & experience and personal appreciation highly favor one criterion over another \\
\hline 7 & very high and corroborated importance & one criterion is strongly favored and its dominance is supported in practice \\
\hline 9 & absolute importance & evidence supporting one criterion over another is as convincing as possible \\
\hline $2,4,6,8$ & values related to intermediate judgments & when a compromise is required \\
\hline
\end{tabular}

Source: SAATY [1990].

Calculation of the weight vector [w] for the factors from the average of the columns for matrix:

$$
p_{j}=\frac{\sum_{j}\left(W_{n j} / B_{j}\right)}{n}
$$

The eigenvector $[\mathrm{w}]=\left(P_{1}, P_{2}, P_{3}, \ldots, P_{n}\right)$ indicates the order of priority or hierarchy of the criteria studied. This result is important for the evaluation of the probability; it is also used to indicate the importance of each operating criterion. The eigenvalue allows evaluating the consistency of the judgments [SAATY 1990].

In order to test the coherence of the judgments, which indicates whether the comparisons have a logical relationship between them, the cited author proposes to follow the next procedure.

Calculation of the coherence index $(C I)$ :

$$
C I=\frac{\lambda_{\max }-n}{n-1}
$$

Where: $\lambda_{\max }$ is the maximum eigenvalue of the comparison matrix which is deduced as following:

$$
\lambda_{\max }=\frac{1}{n} \sum_{j} d_{j} / p_{j} \quad \text { and } \quad d_{j}=\sum_{i} p_{i} \cdot W_{i j}
$$

The coherence ratio $(c r)$ is calculated using the equation: $c r=C I: R I$. Where the random inconsistency index $(R I)$ is determined by simulation (Tab. 3):
Table 3. Random inconsistency indices $(R I)$

\begin{tabular}{|c|c|c|c|c|c|c|c|c|c|}
\hline$n$ & 3 & 4 & 5 & 6 & 7 & 8 & 9 & 10 & 11 \\
\hline$R I$ & 0.58 & 0.90 & 1.12 & 1.24 & 1.32 & 1.41 & 1.45 & 1.49 & 1.51 \\
\hline
\end{tabular}

Explanation: $n=$ the number of criteria to compare.

Source: SAATY [1990], modified.

The judgment is considered as acceptable for a coherence ratio smaller than 0.1 [SAATY 1990]. In the second step (block B), a rating system is assigned to all the elements that are at the basis of our hierarchical structure. The notation used depends on the problem at hand which in the present case is the calculation of the runoff coefficient.

\section{RESULTS AND DISCUSSION}

\section{Model 1: Modelling of runoff coefficient based on vegetation cover, slope and soil type}

First, the results given in Table 4 were taken into account [DDTM34 2014].

The impact of each criterion, i.e. vegetation cover, soil type and slope, on runoff is determined in this phase. These three criteria are then ranked according to their impacts.

From Table 4, it can be seen that the runoff coefficient $(R C)$ can be determined using the following formula: 


$$
R C=\left(P_{v} . N_{v}+P_{t} \cdot N_{t}+P_{p} . N_{p}\right): 10
$$

Where $P_{t}, P_{v}$ and $P_{p}$ are invariant values between 0 and 1; they represent the weight of each criterion, namely the type of soil, vegetation cover and slope, respectively. Furthermore, $N_{t}, N_{v}$ and $N_{p}$ are values between 0 and 10; they represent the impact of the variation of each criterion, i.e. the type of soil, vegetation cover and gradient, on runoff, respectively.

Our study aims to determine the effective values of these weights as well as those of $N_{t}, N_{v}$ and $N_{p}$.

Table 4. Value of the runoff coefficient $(R C)$ as a function of vegetation cover, slope and type of soil

\begin{tabular}{|l|c|c|c|c|}
\hline $\begin{array}{c}\text { Vegetation } \\
\text { cover }\end{array}$ & $\begin{array}{c}\text { Slope } \\
\%\end{array}$ & $\begin{array}{c}\text { Coarse } \\
\text { sand }\end{array}$ & $\begin{array}{c}\text { Loamy } \\
\text { soil }\end{array}$ & $\begin{array}{c}\text { Clayey } \\
\text { soil }\end{array}$ \\
\hline \multirow{3}{*}{$\begin{array}{l}\text { Wood or } \\
\text { pastureland }\end{array}$} & $p<5$ & 0.10 & 0.30 & 0.40 \\
\cline { 2 - 5 } & $5 \leq p<10$ & 0.25 & 0.35 & 0.50 \\
\cline { 2 - 5 } Crop & $10 \leq p<30$ & 0.30 & 0.50 & 0.60 \\
\cline { 2 - 5 } & $5 \leq p<10$ & 0.30 & 0.50 & 0.60 \\
\cline { 2 - 5 } & $10 \leq p<30$ & 0.40 & 0.60 & 0.70 \\
\hline \multirow{2}{*}{ Cos } & 0.52 & 0.72 & 0.82 \\
\hline
\end{tabular}

Source: DDTM34 [2014].

\section{- Weight structure}

The criteria considered are presented in a hierarchical structure (Fig. 2) which consists of 2 levels.

- level 0 , which aims at defining explicitly the main objective of our problem. Its main objective is to determine the runoff coefficient;

- level 1, which involves the type of soil, vegetation cover and slope.

In order to assign a weight to each criterion, the comparisons presented in Table 5 are considered.

\section{- Rating criteria}

The weights calculated in the previous step are invariant. However, the criteria considered in the arborescence vary from one basin to another. In order to explain their variations and their impact on the runoff coefficient, it is necessary to develop a rating system that allows evaluating each criterion. Each criterion attribute is scored from 0 to 10 , depending on its influence on the runoff coefficient. The results obtained in our case are presented in Table 6 (Model 1).
Table 6. Criteria's rating

\begin{tabular}{|c|c|c|c|}
\hline $\begin{array}{l}\text { Model } \\
\text { number }\end{array}$ & Criterium & Characteristics & Grading \\
\hline \multirow{8}{*}{ 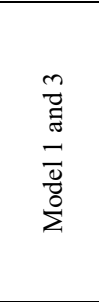 } & \multirow{2}{*}{ vegetation cover } & wood or pastureland & 2 \\
\hline & & crop & 6 \\
\hline & \multirow{3}{*}{ soil type } & coarse sand & 0 \\
\hline & & loamy soil & 7 \\
\hline & & clayey soil & 10 \\
\hline & \multirow{3}{*}{ slope $(\%)$} & $p<5$ & 0 \\
\hline & & $5 \leq p<10$ & 5 \\
\hline & & $10 \leq p<30$ & 10 \\
\hline \multirow{9}{*}{ 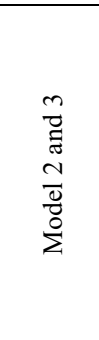 } & \multirow{4}{*}{$\begin{array}{l}\text { maximum daily } \\
\text { precipitation } \\
(P j, \mathrm{~mm})\end{array}$} & $0.80<P j \leq 80$ & 2 \\
\hline & & $80<P j \leq 150$ & 6 \\
\hline & & $150<P j \leq 200$ & 8 \\
\hline & & $P j \geq 200$ & 10 \\
\hline & \multirow{5}{*}{$\begin{array}{l}\text { surface area } \\
\left(S, \mathrm{~km}^{2}\right)\end{array}$} & $S \leq 0.1$ & 10 \\
\hline & & $0.1<S \leq 2$ & 6 \\
\hline & & $2<S \leq 10$ & 4 \\
\hline & & $10<S \leq 100$ & 2 \\
\hline & & $S>100$ & 1 \\
\hline \multirow{4}{*}{$\frac{N}{\frac{\pi}{0}}$} & \multirow{4}{*}{ soil category } & type A & 10 \\
\hline & & type B & 8 \\
\hline & & type $\mathrm{C}$ & 5 \\
\hline & & type $\mathrm{D}$ & 1 \\
\hline
\end{tabular}

Source: own study.

From Equation (4) and the results presented in Tables 5 and 6 , it is possible to estimate the value of the coefficient of runoff, as shown in Table 7.

Table 7. Theoretical value of the runoff coefficient $(R C)$, model 1

\begin{tabular}{|c|c|c|c|c|}
\hline $\begin{array}{c}\text { Vegetation } \\
\text { cover }\end{array}$ & $\begin{array}{c}\text { Slope } \\
\%\end{array}$ & $\begin{array}{c}\text { Coarse } \\
\text { sand }\end{array}$ & $\begin{array}{c}\text { Loamy } \\
\text { soil }\end{array}$ & $\begin{array}{c}\text { Clayey } \\
\text { soil }\end{array}$ \\
\hline \multirow{3}{*}{$\begin{array}{c}\text { Wood or } \\
\text { pastureland }\end{array}$} & $p<5$ & 0.1 & 0.31 & 0.4 \\
\cline { 2 - 5 } & $5 \leq p<10$ & 0.2 & 0.41 & 0.5 \\
\cline { 2 - 5 } & $10 \leq p<30$ & 0.3 & 0.51 & 0.6 \\
\hline \multirow{3}{*}{ Crop } & $p<5$ & 0.3 & 0.51 & 0.6 \\
\cline { 2 - 5 } & $5 \leq p<10$ & 0.4 & 0.61 & 0.7 \\
\cline { 2 - 5 } & $10 \leq p<30$ & 0.5 & 0.71 & 0.8 \\
\hline
\end{tabular}

Source: own study.

It is worth noting that the theoretical runoff coefficient value coincides with the experimental value (Fig. 3), which proves the validity of our method.

Table 5. Binary comparisons of criteria, weights of criteria and consistency of judgments

\begin{tabular}{|c|c|c|c|c|c|c|c|}
\hline Model number & Criteria & Vegetation cover & Soil type & Slope & Weight & $C I$ & $\mathrm{Cr}$ \\
\hline \multirow{3}{*}{ Model 1 and 3} & vegetation cover & 1 & 2 & 2 & 0.5 & \multirow{3}{*}{0.027} & \multirow{3}{*}{0.046} \\
\hline & soil type & $1 / 2$ & 1 & 2 & 0.3 & & \\
\hline & slope & $1 / 2$ & $1 / 2$ & 1 & 0.2 & & \\
\hline \multirow{3}{*}{ Model 2 and 3} & & precipitation & watershed & weight & \multirow{9}{*}{\multicolumn{3}{|c|}{$\begin{array}{l}\text { Consistency of judgments is verified only } \\
\text { for comparison between three or more } \\
\text { criteria. When working with two criteria } \\
\text { the judgment is simple and you can not } \\
\text { make mistakes }\end{array}$}} \\
\hline & precipitation & 1 & $1 / 3$ & 0.25 & & & \\
\hline & watershed & 3 & 1 & 0.75 & & & \\
\hline \multirow{3}{*}{ Model 2} & & soil category & surface area & weight & & & \\
\hline & soil category & 1 & 2 & 0.67 & & & \\
\hline & surface area & $1 / 2$ & 1 & 0.33 & & & \\
\hline \multirow{3}{*}{ Model 3} & & infiltration & surface area & weight & & & \\
\hline & infiltration & 1 & 2 & 0.67 & & & \\
\hline & surface area & $1 / 2$ & 1 & 0.33 & & & \\
\hline
\end{tabular}

Explanations: $C I=$ coherence index, $\mathrm{cr}=$ coherence ratio.

Source: own study. 


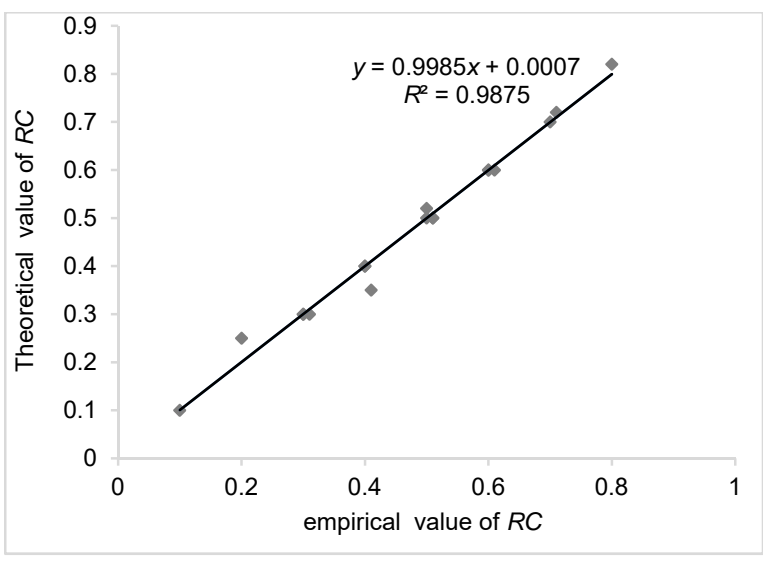

Fig. 3. Adjustment of theoretical and empirical value of runoff coefficient $(R C)$, model 1; source: own study
Model 2: Modelling the runoff coefficient as a function of rainfall and surface area of the watershed

In Algeria, the runoff coefficient is determined on the basis of the classification drawn up by the National Agency for Hydraulic Resources (Fr. Agence Nationale des Ressources Hydrauliques - ANRH); it depends on the size of the basin, the maximum daily rainfall and type of soil (Tab. 8). According to Table 8 , it is clear that the runoff coefficient can be defined by the following formula:

$$
R C=\left(P_{p l} \cdot N_{\mathrm{pl}}+P_{c} \cdot N_{c}+P_{s} \cdot N_{s}\right): 10
$$

Where: $P_{c}, P_{s}$ and $P_{p l}$ are the weights of criteria, i.e. soil category, surface area of basin and rainfall, respectively. Similarly, $N_{c}, N_{s}$ and $N_{p l}$ represent the scores of the same criteria, respectively.

Table 8. Classification of runoff coefficient according to the National Agency for Hydraulic Resources

\begin{tabular}{|c|c|c|c|c|c|c|c|}
\hline \multirow[b]{2}{*}{ Type of soil } & \multirow[b]{2}{*}{ Soil designation } & \multirow{2}{*}{$\begin{array}{l}\text { Maximum daily rainfall } \\
\qquad P j(\mathrm{~mm})\end{array}$} & \multicolumn{5}{|c|}{ Surface area of watersheds $\left(\mathrm{km}^{2}\right)$} \\
\hline & & & $<0.1$ & $\begin{array}{l}>0.1 \\
<2.0\end{array}$ & $\begin{array}{l}>2.0 \\
<10\end{array}$ & $\begin{array}{l}>10.0 \\
<100.0\end{array}$ & $>100$ \\
\hline \multirow{4}{*}{ A } & \multirow{4}{*}{$\begin{array}{l}\text { fat clay soils, crusts, and } \\
\text { encrusted soils }\end{array}$} & $>0.8$ & 0.80 & 0.70 & 0.65 & 0.65 & 0.60 \\
\hline & & $81-150$ & 0.90 & 0.85 & 0.80 & 0.80 & 0.80 \\
\hline & & $151-200$ & 0.95 & 0.90 & 0.90 & 0.90 & 0.90 \\
\hline & & $>200$ & 0.95 & 0.95 & 0.95 & 0.90 & 0.90 \\
\hline \multirow{5}{*}{$\mathrm{B}$} & \multirow{5}{*}{$\begin{array}{l}\text { clay soils, gray clay forest } \\
\text { soils, heavy gray clay soils }\end{array}$} & $>0.8$ & 0.70 & 0.60 & 0.55 & 0.55 & 0.45 \\
\hline & & $81-100$ & 0.80 & 0.75 & 0.70 & 0.65 & 0.65 \\
\hline & & $101-150$ & 0.85 & 0.80 & 0.75 & 0.65 & 0.65 \\
\hline & & $151-200$ & 0.85 & 0.85 & 0.80 & 0.70 & 0.70 \\
\hline & & $>200$ & 0.90 & 0.90 & 0.80 & 0.75 & 0.75 \\
\hline \multirow{4}{*}{$\mathrm{C}$} & \multirow{4}{*}{$\begin{array}{l}\text { chestnut soils, loess, car- } \\
\text { bonated soils }\end{array}$} & $>0.8$ & 0.55 & 0.45 & 0.40 & 0.35 & 0.30 \\
\hline & & $81-150$ & 0.65 & 0.55 & 0.50 & 0.45 & 0.40 \\
\hline & & $151-200$ & 0.75 & 0.70 & 0.65 & 0.60 & 0.55 \\
\hline & & $>200$ & 0.80 & 0.75 & 0.70 & 0.65 & 0.60 \\
\hline \multirow{4}{*}{$\mathrm{D}$} & \multirow{4}{*}{$\begin{array}{l}\text { sandy loam soils, chestnut } \\
\text { and brown grey soils of the } \\
\text { steppe and desert areas, } \\
\text { sandy-loamy gray soils }\end{array}$} & $>0.8$ & 0.35 & 0.28 & 0.20 & 0.20 & 0.15 \\
\hline & & $81-150$ & 0.45 & 0.35 & 0.25 & 0.25 & 0.20 \\
\hline & & $151-200$ & 0.55 & 0.45 & 0.40 & 0.35 & 0.30 \\
\hline & & $>200$ & 0.60 & 0.55 & 0.50 & 0.45 & 0.40 \\
\hline
\end{tabular}

Source: National Agency for Hydraulic Resources (NAHR).

Following the same methodology used in model 1, one can determine the impact of each of these criteria on the runoff coefficient.

\section{- Weight structure}

In this model, two main criteria are considered, namely the precipitation and the characteristics of the watershed. Also, two sub-criteria characterize the basin, namely soil category and surface area. The criteria under consideration are presented in a hierarchical structure consisting of 3 levels (Fig. 4).

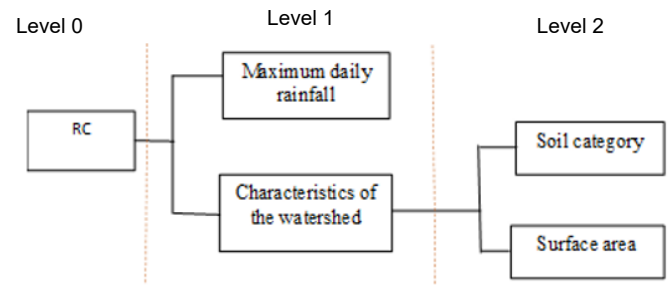

Fig. 4. Hierarchical structure of the runoff coefficient $(R C)$ for model 2; source: own elaboration
Two matrices must be determined; the first one contains the criteria relating to level 1 , and the second one those relative to level 2 . It is assumed that the influence of the basin characteristics is three times greater than that of precipitation, and the soil category is two times larger than that of the surface area of the basin (Tab. 5, model 2).

\section{- Rating criteria}

Similarly to model 1 , a rating system (Tab. 6; model 2) is developed in order to explain the influence of the variation of each criterion on the value of the runoff coefficient.

The runoff coefficient is calculated with the following Equation:

$$
R C=\left[P_{p l} N_{p l}+P_{b}\left(P_{c} N_{c}+P_{s} N_{s}\right)\right]: 10
$$

Where $P_{b}$ is the characteristic weight of the watershed.

Using formula (6) and the results presented in Tables 5 and 6 , the value of $R C$ was estimated, as shown in Table 9. 
Table 9. Theoretical values of the runoff coefficient $(R C)$, model 2

\begin{tabular}{|c|c|c|c|c|c|c|c|}
\hline \multirow{2}{*}{ Soil type } & \multirow{2}{*}{ Soil designation } & \multirow{2}{*}{$\begin{array}{l}\text { Maximum daily rainfall } P j \\
(\mathrm{~mm})\end{array}$} & \multicolumn{5}{|c|}{ Surface area of watersheds $\left(\mathrm{km}^{2}\right)$} \\
\hline & & & $S \leq 0.1$ & $0.1<S \leq 2$ & $2<S \leq 10$ & $10<S \leq 100$ & $S>100$ \\
\hline \multirow{5}{*}{ A } & \multirow{5}{*}{$\begin{array}{l}\text { fat clay soils, crusts, and } \\
\text { encrusted soils }\end{array}$} & $P_{j} \leq 0.8$ & 0.80 & 0.70 & 0.60 & 0.50 & 0.40 \\
\hline & & $0.80<P_{j} \leq 80$ & 0.85 & 0.75 & 0.65 & 0.55 & 0.45 \\
\hline & & $80<P_{j} \leq 150$ & 0.90 & 0.80 & 0.70 & 0.60 & 0.50 \\
\hline & & $150<P_{j} \leq 200$ & 0.95 & 0.85 & 0.75 & 0.65 & 0.55 \\
\hline & & $P_{j} \geq 200$ & 1.00 & 0.90 & 0.80 & 0.70 & 0.60 \\
\hline \multirow{5}{*}{ B } & \multirow{5}{*}{$\begin{array}{l}\text { clay soils. gray clay forest } \\
\text { soils, heavy gray clay soils }\end{array}$} & $P_{j} \leq 0.8$ & 0.75 & 0.65 & 0.55 & 0.45 & 0.35 \\
\hline & & $0.80<P_{j} \leq 80$ & 0.80 & 0.70 & 0.60 & 0.50 & 0.40 \\
\hline & & $80<P_{j} \leq 150$ & 0.85 & 0.75 & 0.65 & 0.55 & 0.45 \\
\hline & & $150<P_{j} \leq 200$ & 0.90 & 0.80 & 0.70 & 0.60 & 0.50 \\
\hline & & $P_{j} \geq 200$ & 0.95 & 0.85 & 0.75 & 0.65 & 0.55 \\
\hline \multirow{5}{*}{$\mathrm{C}$} & \multirow{5}{*}{$\begin{array}{l}\text { chestnut soils, loess, car- } \\
\text { bonated soils }\end{array}$} & $P_{j} \leq 0.8$ & 0.60 & 0.50 & 0.40 & 0.30 & 0.20 \\
\hline & & $0.80<P_{j} \leq 80$ & 0.65 & 0.55 & 0.45 & 0.35 & 0.25 \\
\hline & & $80<P_{j} \leq 150$ & 0.70 & 0.60 & 0.50 & 0.40 & 0.30 \\
\hline & & $150<P_{j} \leq 200$ & 0.75 & 0.50 & 0.55 & 0.45 & 0.35 \\
\hline & & $P_{j} \geq 200$ & 0.80 & 0.70 & 0.60 & 0.50 & 0.40 \\
\hline \multirow{5}{*}{ D } & \multirow{5}{*}{$\begin{array}{l}\text { sandy loam soils, chestnut } \\
\text { and brown grey soils of } \\
\text { the steppe and desert are- } \\
\text { as, sandy-loamy grey soils }\end{array}$} & $P_{j} \leq 0.8$ & 0.55 & 0.45 & 0.35 & 0.25 & 0.15 \\
\hline & & $0.80<P_{j} \leq 80$ & 0.60 & 0.50 & 0.40 & 0.30 & 0.20 \\
\hline & & $80<P_{j} \leq 150$ & 0.65 & 0.55 & 0.45 & 0.35 & 0.25 \\
\hline & & $150<P_{j} \leq 200$ & 0.70 & 0.60 & 0.50 & 0.40 & 0.30 \\
\hline & & $P_{j} \geq 200$ & 0.75 & 0.65 & 0.55 & 0.45 & 0.35 \\
\hline
\end{tabular}

Source: own study.

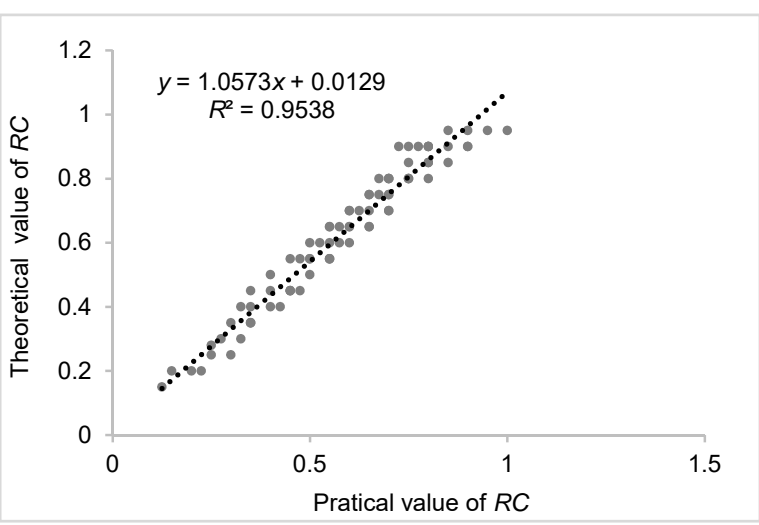

Fig. 5. Adjustment of theoretical and empirical value of runoff coefficient $(R C)$, model 2; source: own study

We validate our work by the adjustment presented in the Figure 5.

\section{Model 3 as a combination of the two models}

One of the major advantages of the analytic hierarchy process (AHP) is that it allows considering a large number of criteria simultaneously; it also makes it possible to be evolutionary, because one can introduce or withdraw one or more criteria at any moment. This property is used to develop a new model that allows estimating the runoff coefficient while combining the results of the two previous models.

\section{- Weight structure}

In model 1 , it is easy to note that the sum of the weights of the three criteria, namely the soil type, vegetation cover and slope is equal to 1 . These criteria have been assembled and linked to a father criterion called infiltration. The hierarchical structure is composed of 4 levels (Fig. 6).

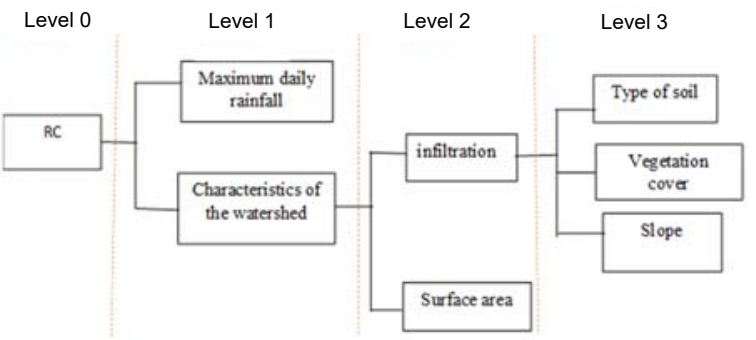

Fig. 6. Hierarchical structure of the runoff coefficient $(R C)$ for model 3; source: own study

Level 0: consists of calculating the $R C$.

Level 1: involves the main criteria, which are the precipitation and watershed characteristics.

Level 2: involves two criteria, i.e. infiltration and surface area, are considered.

Level 3: has the three criteria, namely the type of soil, vegetation cover and slope.

The comparisons considered in model 1 and that between the precipitation and the basin in model 2 are maintained (Tab. 5), we only introduce comparisons between infiltration and surface area (Tab. 5, model 3).

\section{- Rating the criteria}

We keep the ratings of models 1 and 2 as shown in Table 6 (model 3).

The value of the runoff coefficient is defined with the following formula:

$R C=\left(P_{p \mathrm{l}} N_{p \mathrm{l}}+P_{b}\left(P_{s} N_{s}+P_{i}\left(P_{c} N_{c}+P_{t} N_{t}+P_{p} N_{p}\right)\right)\right): 10$

Where $P_{i}$ is the weight of the soil infiltration criterion.

Considering the results reported in Tables 5 and 6 , it becomes possible to determine the value of the runoff coefficient. 


\section{- Case study applying the model 3}

The Wadi Bou-Kiou in small watershed is located in the North-West of Algeria (Fig. 7). The drained area is about $3.05 \mathrm{~km}^{2}$ and the perimeter of $9 \mathrm{~km}$. The length of the main thalweg is $3.37 \mathrm{~km}$. The slope, $I p=5.8 \%$, is estimated by the Roche index of which a hypsometric curve is used.

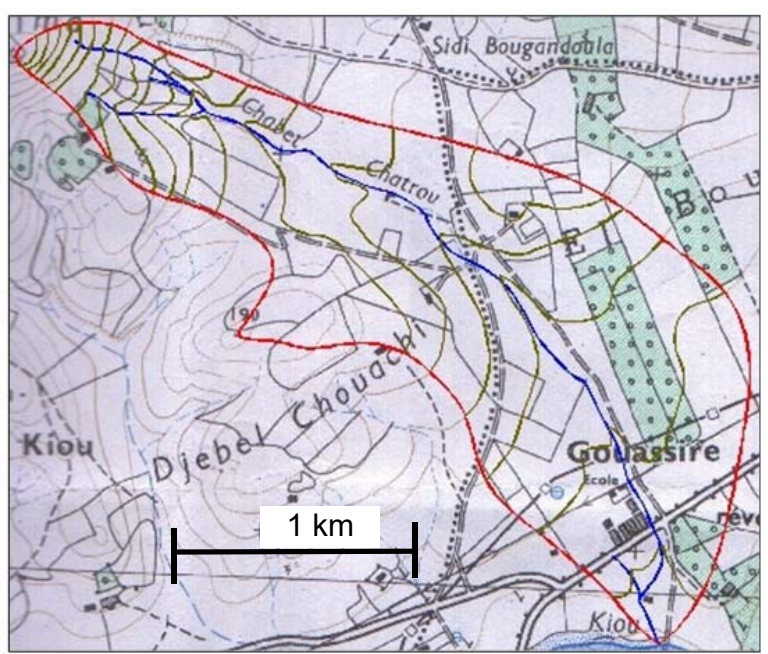

Fig. 7. Study area - general information; source: Water and Environment Engineering Design Office

The basin mainly consists of clay soil and a large part of the vegetation cover is forests and pastures. The rainfall data were recorded at the professional meteorology station, called Remchi (latitude $35^{\circ} 03$ '34" N, longitude $01^{\circ} 25^{\prime} 33^{\prime}$ ' W, altitude $284 \mathrm{~m}$ ) and span the period from 1982 to 2012 .

According to the high value of the coefficient of determination, the annual maximal daily rainfall series is well fitted to the Gumbel distribution using the weight moments (Fig. 8).

From Figure 8 we deduce the maximum daily precipitation for different return periods (Tab. 10).

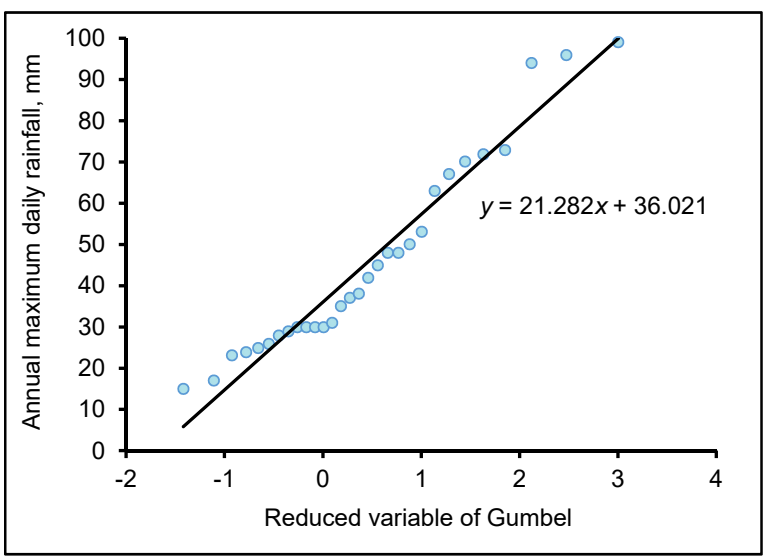

Fig. 8. Adjustment of Gumbel's Law; source: Water and Environment Engignering Design Office

The results of model 3 allow us to estimate the $R C$ of this watershed for different return periods of the annual maximum daily rainfall (Tab. 10). The re-
Table 10. Runoff coefficient $(R C)$ estimation corresponding to annual maximum daily rainfall for different return period

\begin{tabular}{|l|c|c|c|c|c|c|}
\hline \multirow{2}{*}{ Parameter } & \multicolumn{6}{|c|}{ Return period (years) } \\
\cline { 2 - 7 } & 2 & 5 & 10 & 20 & 50 & 100 \\
\hline $\begin{array}{l}\text { Maximum daily } \\
\text { rainfall (mm) }\end{array}$ & 44 & 67.9 & 83.91 & 99.23 & 119 & 133.66 \\
\hline$R C$ & 0.4 & 0.4 & 0.5 & 0.5 & 0.5 & 0.5 \\
\hline
\end{tabular}

Source: own study.

sults of model 3 allow us to estimate the $R C$ of this watershed for different return periods of maximum daily rainfall (Tab. 11).

\section{Impact of the criteria on the runoff coefficient.}

For the three models, Table 5 was used to calculate the impact of each criterion on the $R C$ (Tab. 11) and the following results are deduced.

Model 1. Note that the runoff coefficient is strongly influenced by the vegetation cover. It is also worth mentioning the impact of the key criterion which is the maximum daily precipitation, besides the size of the watershed.

Model 2. It is noted, on the one hand, that the surface area of the basin and the maximum daily precipitation have virtually the same degree of influence on the runoff coefficient $(R C)$. On the other hand, the soil category has the greatest impact on $R C$. Moreover, in this classification, the soil category is considered in an approximate way.

Model 3. From Table 11, one can say that the maximum daily precipitation and the surface of the watershed have as much influence on runoff as the vegetation cover. Moreover, the influence of the soil type and the slope is not negligible.

This argues in favour of the high dependence of the runoff coefficient $(R C)$ on all the criteria previously considered.

\section{CONCLUSION AND PERSPECTIVES}

In the light of the results obtained, it was possible to demonstrate that the influence of each criterion, contributing to the runoff, may be treated separately. Note that it is the vegetation cover and the surface of the watership that have the greatest impact on the coefficient of runoff. This result is in harmony with the weights previously discussed. The use of the hierarchical analysis process made it possible to carry out a theoretical estimate of the influence of the five criteria, namely precipitation, vegetation cover, surface area, slope and soil type on the runoff coefficient $(R C)$. Furthermore, this process allowed understanding the behaviour of surface water runoff.

On the other hand, it was possible to perform a mathematical interpretation and a numerical quantification of the influence of each of the operative criteria on the coefficient of runoff. The proposed model is evolutionary and can be adapted to several types and numbers of criteria related to the phenomenon. The main research perspectives that emerge from this 
work are the possibility of introducing other criteria that may have an impact on the runoff of water. These include the human action, land use, intensity and duration of precipitation and the groundwater.

\section{REFERENCES}

ABBAS H.B., RoutRay J.K. 2014. Assessing factors affecting flood-induced public health risks in Kassala State of Sudan. Operations Research for Health Care. Vol. 3 p. $215-225$.

Aragones-Beltrán P., Pastor-Ferrando J., GarciaGarcia F., Pascual-Agullo A. 2010. An analytic network process approach for siting a municipal solid waste plant in the Metropolitan Area of Valencia (Spain). Journal of Environmental Management. Vol. 91. Iss. 5 p. 1071-1086.

Balades J.D., Monfort M., Gaber J. 2004. Plan de prévention des risques naturels (PPR). Les risques d'innondation. Le ruissellement urban [Natural Risk Prevention Plan (PPR). Risks of flooding. Urban runoff] [online]. Paris. DPPR-SDPR pp. 60. [Access 15.11.2017]. Available at: http://www.mementodumaire.net/wpcontent/ uploads/2012/07/MEDD-PPRI-ruissellementperiurbain-2004.pdf

DDTM34 2014. Guide méthodologique pour la gestion des eaux pluviales dans les projets d'aménagement. T. 2 . Méthode d'investigation et de dimensionnement [Methodological guide for stormwater management in development projects. T. 2. Investigation and sizing method] [online] pp. 112. [Access 10.11.2017]. Availa- ble at: http://www.gesteau.fr/sites/default/files/guidepluvial tome2miseenpage.pdf

ENNAOURI I., FuAmBA M. 2010. Modélisation de la dégradation hydraulique et structurale des réseaux sanitaires et pluviaux [Modeling of hydraulic and structural degradation of sewer and storm water pipelines]. MSc Thesis. Civil Engineering. Polytechnic School of Montreal. Montreal University pp. 79.

GRZYwNA A. 2017. The change of quantity and quality out flow of water in Ochożanka River basin. Journal of Water and Land Development. No. 35 p. 57-62. DOI 10.1515/jwld-2017-0068.

HACHOŁ J., HÄMMERLING M., BONDAR-NOWAKOWSKA E. 2017. Applying the analytical hierarchy process (AHP) into the effects assessment of river training works. Journal of Water and Land Development. No. 35 p. 63-72. DOI 10.1515/jwld-2017-0069.

ORENCIO P.M., FUJII M. 2013. A localized disasterresilience index to assess coastal communities based on an analytic hierarchy process (AHP). International Journal of Disaster Risk Reduction. Vol. 3 p. 62-75.

Ouyang X., Guo F., Shand D., Yu H., Wang J. 2015. Development of the integrated fuzzy analytical hierarchy process with multidimensional scaling in selection of natural wastewater treatment alternatives. Ecological Engineering. Vol. 75 p. 438-447.

SAATY T.L 1990. How to make a decision. The analytic hierarchy process. European Journal of Operational Research. Vol. 48 p. 9-26.

Willett K., SHARDA R. 1991. Using the analytic hierarchy process in water resources planning: Selection of flood control projects. Socio-Economic Planning Sciences. Vol. 25. Iss. 2 p. 103-112.

\section{Faiza LALLAM, Abdesselam MEGNOUNIF, Abderrahman Nekkache GHENIM}

\section{Ocena współczynnika odpływu za pomocą metody hierarchicznej analizy problemów decyzyjnych}

\section{STRESZCZENIE}

Współczynnik odpływu $(R C)$ jest parametrem często używanym w hydrologii wód powierzchniowych w celu charakterystyki zdolności drenarskiej zlewni. Tradycyjnie ocenę tego współczynnika wykonuje się za pomocą obliczeń bazujących maksymalnie na 2-3 parametrach. W niniejszej pracy przedstawiono trzy modele numeryczne. Dwa z nich oparte są na badaniach eksperymentalnych. Pierwszy bazuje na trzech kryteriach: pokrycie roślinnością, typ gleby i nachylenie terenu. Drugi uwzględnia rozmiar zlewni, maksymalny opad dobowy i typ gleby. W praktyce nie jest łatwo ocenić współczynnik odpływu przez uwzględnienie wpływu kilku kryteriów równocześnie. Aby rozwiązać ten problem, zbudowano i przedstawiono trzeci model. Umożliwia on połączenie informacji z dwóch wyżej wymienionych modeli. Celem pracy jest umożliwienie weryfikacji porównywalności kryteriów i dokonanie oceny względnego znaczenia każdego z nich.

Słowa kluczowe: maksymalny opad dobowy, metoda hierarchicznej analizy problemów decyzyjnych, nachylenie, pokrywa roślinna, powierzchnia zlewni, typ gleby, współczynnik odpływu 